\title{
Lietelannan kasvinravinnepitosuuksista
}

\author{
JORMA KÄHÄRI \\ Maatalouden tutkimuskeskus, Maanviljelyskemian ja -fysiikan laitos, \\ 01300 Vantaa
}

\section{Plant nutrient content of liquid manure}

JoRMA KÄHÄRI

Agricultural Research Centre, Department of Agricultural Chemistry and Physics, 01300 Vantace

\begin{abstract}
The plant nutrient contents of 51 liquid manure samples were determined. The material, which consisted of 31 cattle manure samples and 20 pig manure samples, was gathered in the years $1964-73$ from experimental stations, the piggeries of dairies and private farms,

The $\mathrm{pH}$-values and the water contents of pig and cattle liquid manure were on an average nearly the same. The plant nutrient contents of pig liquid manure were usually higher and the range of the nutrient contents was larger than in the cattle liquid manure. The contents of potassium, iron and manganese per dry matter were equal in both manures.

The percentage of the soluble fraction of the total nitrogen in pig liquid manure was three times and in cattle liquid manure twice as high as that in cattle manure from stall and loose housing barns. The content of total nitrogen in pig liquid manure was noticeably high when compared with the potassium content.

On the basis of the results it can be calculated that when $40000 \mathrm{~kg}$ per hectare of liquid manure is used, calcium, magnesium and micronutrients in amounts adequate to the 1-2 years need of cereals will accumulate in the soil.

The plant nutrient contents of liquid manure analysed in this study did not seem to differ markedly from data available in literature.
\end{abstract}

Lannan talteenotto lietelantana on yleistynyt viime vuosina maamme karjatalouksissa. Syynä tähän on lietelantajärjestelmän aiheuttama ihmistyön tarpeen väheneminen ja työn helpottuminen, vaikka toisaalta on syntynyt uusia ongelmia lannan varastoinnissa, kuljetuksessa ja oikeassa käytössä.

Lietelantaa, sen käyttöä ja lannoitusvaikutusta selvitteleviä tutkimustulokia on julkaistu Suomessa vähän (esim. KERÄNEN 1966, LAINE 1967, KoRKMAN 1971, 1974). Näiden tulosten perusteella ei saada riittävän tarkkoja tietoja eri eläinten lietelannan koostumuksesta ja lannoitusvaikutuksesta, joita edellytetään sopivien käyttömäärien selville saamiseksi.

Tämän tutkimuksen tarkoituksena oli määrittää naudan ja sian lietelannan kasvinravinnepitoisuuksia ja pitoisuuksien vaihtelurajoja. 
Näytteet kerättiin vuosina $1964-73$ eri koeasemilta ja koeasemien sekä paikalliskoetoimiston välityksellä yksityisiltä tiloilta ja meijereitten sikaloista. Vuosittaiset näytemäärät olivat naudan (N) ja sian (S) lietelantojen osalta seuraavat:

\begin{tabular}{rrrrrrrrrr} 
& \multicolumn{10}{c}{ Vuosi } \\
& 64 & 65 & 67 & 68 & 70 & 71 & 72 & 73 & Yht. \\
$\mathrm{N}$ & 2 & 4 & 8 & 2 & 2 & 1 & 6 & 6 & 31 \\
$\mathrm{~S}$ & - & - & 1 & - & 2 & 4 & 9 & 4 & 20
\end{tabular}

Näytemäärät eri paikoista jakautuivat seuraavasti:

\begin{tabular}{|c|c|}
\hline & $\mathrm{N}$ \\
\hline 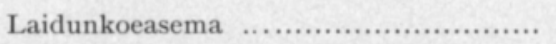 & 12 \\
\hline 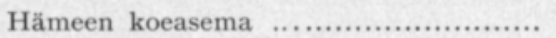 & 7 \\
\hline 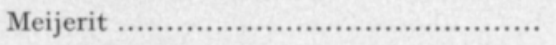 & - \\
\hline Yksityiset tilat & 12 \\
\hline
\end{tabular}

Näytteet esikäsiteltiin tai pakastettiin välittömästi. Pakastettujen näytteiden annettiin sulaa huoneenlämmössä ennen esikäsittelyä. Esikäsittelyssä näytteet, jotka olivat 1-2 litran suuruisia, homogenisoitiin ja niistä otettiin osanäytteet eri analyyseihin.

Lannan pH määritettiin potentiometrisesti suoraan osanäytteestä. Kuivaaine määritettiin $200 \mathrm{~g}$ erästä haihduttamalla kuiviin vesihauteella ja kuivaamalla näytettä yhden tunnin ajan 70 C lämpötilassa ja lopuksi 1 t 130 c:ssa. Kokonaistyppimääritys tehtiin $50 \mathrm{~g}$ suuruisesta, tuoreena punnitusta näytteestä Kjeldahl-poltolla. Liukoisen typen määritystä varten $100 \mathrm{~g}$ suuruiseen näytteeseen lisättiin $50 \mathrm{ml} 2 \mathrm{~N} \mathrm{HCl} \mathrm{ja} 50 \mathrm{ml} 5 \mathrm{~N} \mathrm{CaCl}_{2}$, huiskutettiin 3 tuntia ja sentrifugoitiin. Typpi määritettiin suodoksesta tislaamalla. Kivennäismäärityksiä varten kuivattua ja hienonnettua näytettä punnittiin $2 \mathrm{~g}$ kvartsimaljaan ja poltettiin tuhkaksi 520 C lämpötilassa yön yli. Tuhka käsiteltiin kahteen kertaan suolahapolla ja suodatettiin. Suodoksesta määritettiin fosfori ammoniumvanadaatti-molybdaatti-menetelmällä. Mittauslaitteena käytettiin Beckman B spektrofotometriä. Kalsium, magnesium, kupari, mangaani, sinkki ja rauta mitattiin Varian Techtron 1200 atomiabsorptiospektrofotometrillä ilma-asetyleeni liekissä sopivista laimennoksista. Kalsiumin ja magnesiumin määritystä varten liuokset puskuroitiin $0.25 \%$ :ksi lantaanin suhteen. Natrium ja kalium määritettiin samalla laitteella ilma-propaani liekkiä käyttäen.

\section{Tulokset ja tarkastelu}

Saadut tulokset esitetään taulukossa 1 erikseen naudan ja sian lietelannan osalta. Jokaisesta näytteestä ei saatu kaikkia mittaustuloksia näytteen liian pienen määrän takia. Neljään naudan lietelantaan oli lisätty superfosfaattia, joten niiden osalta fosfori- ja kalsiumpitoisuuksia ei esitetä. 
Taulukko 1. Naudan ja sian lietelannan $\mathrm{pH}$-arvot, vesi- ja ravinnepitoisuudet.

Table 1. The pH-value, water content, and contents of plant nutrients in cattle and pig liquid manures.

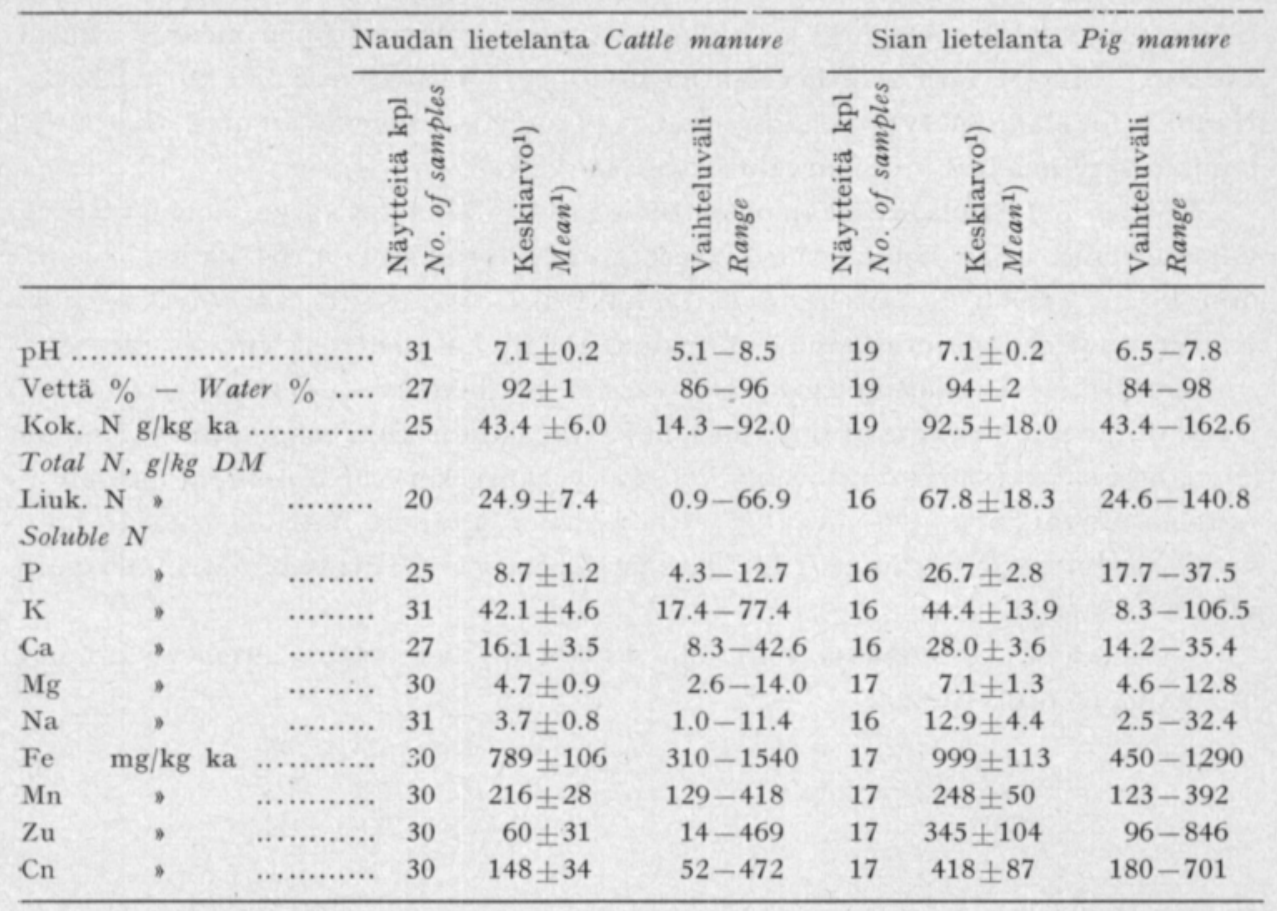

1) Keskiarvot $95 \%$ :n luotettavuusrajoineen.

1) Means with the confidence limits at the $95 \%$ level.

Naudan ja sian lietelannan $\mathrm{pH}$-luvut ja vesipitoisuudet eivät näytä poikkeavan toisistaan. Sen sijaan sian lietelannan ravinnepitoisuudet ovat selvästi korkeampia kuin naudan lietelannan. Vain kaliumin, raudan ja mangaanin pitoisuudet ovat lähes samansuuruiset kummassakin lietelannassa. Yleisenä piirteenä voidaan todeta, että sian lietelannan ravinteiden pitoisuuksien vaihteluväli on suurempi kuin naudan lietelannassa; poikkeuksena on mainittava kalsium- ja rautapitoisuudet.

Lietelannan kuiva-aineen typpipitoisuudet ovat korkeita verrattuna tavalliseen parsinavetta- ja pihattolantaan, joissa KERÄSEN (1966) tulosten mukaan pitoisuus on keskimäärin $25.5 \mathrm{~g} / \mathrm{kg}$. Sian lietelannan typestä on keskimäärin $73 \%$ liukoista. Naudan lietelannan typestä vastaava arvo on $\mathbf{5 7} \%$. Parsinavetta- ja pihattolannassa liukoisen typen osuus on vain $21 \%$ kokonaistypestä (KERÄNEN 1966).

Seuraavassa asetelmassa on esitetty ravinnesuhteet $(\mathrm{N}: \mathrm{P}: \mathrm{K})$ eri lantalajeista.

$\mathrm{N}: \mathrm{P}: \mathrm{K}$

Naudan lietelanta .............................. $1: 0.20: 0.96$

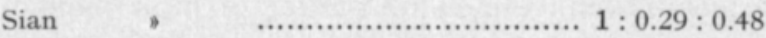

Parsinavettalanta (KERÄNEN 1966) .......... $1: 1.29: 1.02$

Pihattolanta (KERÄNEN 1966) ............... $1: 0.16: 1.20$ 
Lietelannoissa typen ja fosforin suhde lienee sopiva, kaliumin suhde typpeen jäänee sian lietelannassa liian pieneksi esimerkiksi vijakasvien tarvetta ajatellen.

Jos lietelantaa käytetään $40000 \mathrm{~kg}$ hehtaaria kohti, tulee maahan naudan lietelannassa keskimäärin $80 \mathrm{~kg}$ liukoista typpeä kokonaistypen määrän ollessa $140 \mathrm{~kg}$. Käytettäessä sian lietelantaa luvut ovat vastaavasti $163 \mathrm{~kg}$ ja $222 \mathrm{~kg}$. Naudan lietelannan typpimäärät ovat sopivia viljakasveille, mutta sian lietelannan typpimäärät ovat arveluttavan korkeita.

Naudan lietelannassa maahan joutuva fosforimäärä ,28 kg/ha, lienee riittävä viljakasveille. Sian lietelantaa käytettäessä fosforimäärä on $64 \mathrm{~kg} / \mathrm{ha}$. Kaliumin osalta $40000 \mathrm{~kg}$ lietelantamäärä näyttäisi olevan riittävä viljakasveille. Kalsiumin ja magnesiumin määrät vastaavat viljakasvien $1-2$ vuoden tarvetta.

Lietelannassa joutuu maahan varsin huomattavia määriä natriumia. Naudan lietelannassa natriumia on lähes yhtä paljon kuin magnesiumia ja sian lietelannassa natriumin pitoisuus on lähes kaksinkertainen magnesiumpitoisuuteen verrattuna. On ilmeistä, että maan sisältämät natrium-määrät nousevat käytettäessä jatkuvasti lietelantaa, koska kasvit ottavat natriumia vain pieniä määriä.

Seuraavassa asetelmassa esitetään $40000 \mathrm{~kg}$ lietelantamäärien sisältämät hievnainemäärät kiloina

$\begin{array}{lrcccc} & & \text { Fe } & \text { Mn } & \text { Cu } & \text { Zn } \\ \text { Naudan lietelanta } & \ldots \ldots \ldots \ldots \ldots \ldots . & 2.5 & 0.7 & 0.2 & 0.5 \\ \text { Sian } & \ldots \ldots \ldots \ldots \ldots \ldots \ldots . & 2.4 & 0.6 & 0.8 & 1.0\end{array}$

Kummassakin lietelannassa tulee maahan huomattavat määrät hivenaineita, mikä on erittäin tärkeä seikka arvioitaessa lietelantojen käyttöäarvoa. Merkittävin ero lietelantojen välillä on kuparin kohdalla.

Saatujen tulosten mukaan ravinnepitoisuudet eivät näytä poikkeavan kovinkaan paljon muualla saaduista (esim. ValdmaA 1964, Vetter ja Klasink 1972, Mc Kenna ym. 1973). Vetterin ja Klasinkin (1972) esittämä naudan lietelannan fosforipitoisuus on huomattavasti suurempi kuin tässä tutkimuksessa. Vastaavasti mangaanin ja sinkin pitoisuudet ovat keskimäärin korkeampia molemmissa lietelannoissa verrattuna nyt saatuihin. Erot johtunevat suurelta osin ruokinnassa käytetyistä rehusuoloista.

\section{Yhteenveto}

Tutkimuksessa on esitetty analyysitulokset $\mathbf{5 1}$ lietelantanäytteestä, joista oli naudan lantanäytteitä $31 \mathrm{kpl}$ ja sian lietelantanäytteitä $20 \mathrm{kpl}$. Näytteet oli kerätty vuosina $1964-73$ eri koeasemilta, meijereitten sikaloista ja yksityisiltä tiloilta.

Sian ja naudan lietelannan $\mathrm{pH}$-arvot ja vesipitoisuudet olivat keskimäärin lähes samansuuruiset. Sian lietelannan ravinnepitoisuudet olivat yleensä korkeampia ja pitoisuuksien vaihelu oli suurempi kuin naudan lietelannassa. Kaliumin, raudan ja mangaanin pitoisuudet kuiva-ainetta kohti olivat molemmissa lietelannoissa samansuuruiset. 
Sian lietelannan liukoisen typen prosenttinen osuus kokonaistypestä oli kolminkertainen ja naudan lietelannassa kaksinkertainen verrattuna parsinavetasta ja pihatosta talteenotettuun naudan lantaan. Sian lietelannan sisältämän typen määrä oli huomattavan korkea verrattuna kaliumin määrään.

Saatujen lukujen perusteella voitiin todeta, että käytettäessä $40000 \mathrm{~kg}$ lietelantaa hehtaaria kohti joutuu maahan kalsiumia, magnesiumia ja hivenravinteita keskimäärin peltokasvien $1-2$ vuoden tarvetta vastaavat määrät.

Tässä tutkimuksessa saadut lietelannan kasvinravinnepitoisuudet eivät näyttäneet poikkeavan merkittävästi muualla saaduista tuloksista.

\section{KIRJALLISUUS}

Keränen, T. 1966. Karjanlannan kasvinravinteet. Maatal. ja Koetoim. 20:7-13.

Korkman, J. 1971. Survival and leaching of fecal streptococci under field conditions. Acta Agr. Fenn. 123: 186-196.

- - 1974. Avdunstning och urlakning - två faktorer som påverker användningen av flytgödseln. Nord. Jordbrukforskn. 56, 1: 73-74.

LAINE, T. 1967. Lietelannan käyttöarvo. Maatal. ja Koetoim. 24, 12: 42.

McKenna, J. R., Brown, C. S. \& Carpenter, P. N. 1973. Fertility content of fluid manure from Maine dairy farms. Univ. Maine Bull. 703.

VETTER, H. \& KLASINK, A. 1972. Untersuchungen zu den Grenzen der Anwendung von Schweineund Hühnergülle. Z. Landw. Forsch. Sonderh. 22:122-134. 